\title{
Martínez Sierra, Juan José (2008), Humor y traducción: Los Simpson cruzan la frontera. En: Collecció "Estudis sobre la traducció", núm. 15, Universitat Jaume I. 271p.
}

La globalización - Macdonaldization (p. 92) - es un hecho y el mundo de la traducción no escapa a sus efectos. La emblemática familia creada por Matt Groening cruzó la frontera española en 1991. A los españoles les gustan los Simpson o mejor dicho, les gusta la versión doblada de la serie hasta tal punto que expresiones como "multiplícate por cero" o "¡mosquis!" han pasado a formar parte del léxico común (p. 50). La clave del éxito de Los Simpson estriba en un tipo de comicidad culturalmente específico. "Los Simpson se tambalea entre aquello sobre lo que se mofa y aquello que al mismo tiempo reproduce. (...) El mismo sistema que ataca es el que hace posible que el show sea un negocio tan lucrativo" (p. 191). El escopo principal de la actividad traductora consiste pues primordialmente en la (re)producción del efecto humorístico buscado en la versión original ( $\mathrm{p}$. 40). Y esto confronta al traductor con una serie de problemas que no son fundamentalmente lingüísticos sino de índole cultural ya que el humor se conceptualiza de manera diferente en cada sociedad (p. 95), en parte porque se basa en un conocmiento previo compartido entre emisor y receptor ( $p$. 123). De ahí que el traductor se conciba esencialmente como experto intercultural (p.99) "no sólo bilingüe sino también bicultural" (p. 234).

Ahora bien, los excelentes índices de audiencia que tiene la serie en España llevan a Martínez Sierra a suponer que el humor audiovisual resulta traducible (p. 233). Eso sí, la conjugación de palabras, imágenes, música, efectos especiales, sonido, colores, etc. le invita al traductor a degustar un "delicado cóctel de compleja composición" (p. 132).

El volumen que aquí se reseña - resumen de una tesis doctoral - se enmarca en el ámbito de los estudios de la traducción audiovisual. Más en particular, Martínez Sierra se propone "desde un enfoque discursivista e intercultural, desarrollar una metodología descriptiva para el estudio contrastivo de la traducción del humor en textos audiovisuales que conduzca a la identificación de tendencias de traducción” (p. 172).

El libro se articula en siete capítulos. Los contenidos teóricos de los cinco capítulos iniciales se ofrecen al lector de forma escalonada y lógica, sentando las bases para el planteamiento empírico de los capítulos sexto y séptimo. El libro se destaca por una claridad y una coherencia asombrosas. En ningún momento el texto se desvía del hilo argumentativo claramente explicado en la introducción y recogido en las primeras líneas de cada parte. Enlazando con la imagen del libro como plato suculento saboreado con "un instrumental exquisito (...) como cubertería fina" (prólogo, p. 14), diría que las porciones teóricas perfectamente equilibradas y fácilmente digeribles (capítulos 1-5) dejan sitio para un excelente postre de chocolate (capítulos 6-7, conclusiones) que, como suele ser el caso, sabe a más. 
El capítulo 1 versa sobre la idiosincrasia de los textos audiovisuales cuya traducción presenta una serie de características propias que la definen como una actividad traductora "a medio camino entre el código restringido (el del discurso oral espontáneo) y el elaborado (el del discurso escrito)" (p. 35). En el capítulo 2 Martínez Sierra se ocupa de la rama descriptiva subrayando la importancia de una base empírica de ejemplos reales que evite caer en la teorización más absoluta (p. 83). Se introducen y se definen los términos estrategias de traducción, tendencias traductoras y normas de traducción (p. 82).

El capítulo 3 ofrece una visión panorámica de los Estudios Culturales e insiste en la relación entre la cultura y el humor. Todos los humanos tenemos sentido del humor pero nos reímos por distintas razones (Klopf, Murcock, Rabadán, p. 95). En el capítulo 4 se trata la cuestión del humor de forma más pormenorizada. Para que un chiste tenga éxito se requiere un conocimiento previo compartido entre el emisor y el receptor (p. 123), lo cual dificulta la labor del traductor. Basándose en Zabalbeascoa, el autor llega a una tipología de elementos humorísticos de los chistes (p. 153). Siguiendo por este camino, en el capítulo 5 se relaciona la traducción del humor con algunas cuestiones de carácter pragmático: las máximas conversacionales, la intencionalidad y el foco contextual (Agost p. 156). El capítulo 6 va dedicado a la descripción del análisis y de la metodología seguida. El capítulo 7 es un capítulo clave en el libro puesto que incluye la aplicación práctica de las distintas posturas más bien teóricas a un corpus de 365 chistes, recogidos de cuatro episodios de Los Simpson. Tras un escrutinio minucioso de la carga humorística de los chistes, el autor nos presenta los datos cuantitativos y cualitativos mediante tablas y fichas para luego identificar una taxonomía de tendencias traductoras. Entre ellas se destacan las siguientes: i) una clara tendencia a conservar el humor de los chistes, ii) en caso de pérdida de la carga humorística, una voluntad de limitarla, iii) el recurso a otras modalidades traductoras, como la subtitulación, iv) el carácter compuesto de los chistes tanto en el texto de origen como en el texto meta, v) una tendencia hacia las soluciones extranjerizantes y vi) al mismo tiempo una tendencia a evitar el uso de elementos sobre la comunidad del sistema cultural meta (p. 243).

Con todo, en el presente volumen Martínez Sierra ha realizado un excelente trabajo de observación y de descripción. Su análisis muestra de manera científica - sin dejar de ser ameno - cómo los chistes de la serie han cruzado la frontera del idioma y de la cultura. Es más, nos alcanza las herramientas y la metodología necesarias para analizar cualquier tipo de humor en cualquier texto audiovisual. Y es precisamente ahí donde reside la originalidad de su acercamiento al humor, el autor no ofrece un análisis subjetivo de un caso particular sino una propuesta de análisis interdisciplinaria, aplicable tanto a la tarea del traductor como a la del analista. Todo ello viene ya acertadamente formulado en el prólogo y se ve confirmado en cada una de las 271 páginas que cuenta el volumen. 


\section{Anne Verhaert - Department of Translators and Interpreters, Artesis University College, Antwerp}

\section{Milton, John \& Paul Bandia (Eds.) (2009). Agents of Transla- tion. Amsterdam/Philadeplphia: John Benjamins. 329p.}

In this volume, Milton and Bandia present thirteen case studies in which translation is used as a way of influencing the target culture and furthering literary, political and personal interests. In the introduction, they examine key concepts related to agency in Translation Studies, including patronage, power, habitus and networking. In their view, agents occupy an intermediary position between a translator and an end user of a translation. This volume, rather than focusing on the functional role of the agent, emphasizes "their role in terms of cultural innovation and change" (2009, p.1). Agents can challenge the dominant system, political as well as literary, and put forward an alternative one.

In the first case study, Georges L. Bastin takes us to Latin America and investigates the role of Francisco de Miranda (1750-1816) as an intercultural forerunner of emancipation in Hispanic America. In this particular case, the actual role of translation is that of having contributed to this emancipation movement, to the creation of a national and continental identity and to the construction of a new culture. Miranda represents "the very model of a politically committed translator and agent of translation, who sees translation as a weapon of emancipation and therefore does not hesitate to manipulate the original by adding or subtracting from the original everything he considers (ir)relevant to his readership" (2009, p.39).

The second case study focuses on the influence of the Revue Britannique on the work of the first Brazilian fiction writers in the $19^{\text {th }}$ century. This French revue was an important mediator or agent of British ideas and cultural forms, adapted to contemporary French critical opinion. Brazilian society was in search of a history and literature, and, through translation, modern ideas and new cultural forms were brought to this particular part of the new world and were subsequently adapted to the local culture's own needs.

In the third study, translation is studied as a form of representation, examining Fukuzawa Yukichi's (1835-1901) representation of the 'other' in $19^{\text {th }}$-century Japan. Yukichi introduced Western civilization to Japan through his translations and agency. Uchiyama studies the translation of Nations around the world (a book on geography) and some editorials written by Yukichi. In these works, the latter represents the civilized West and uncivilized 'others', a representation that in Japan has had lingering effects on the formation of stereotypical images of other cultures.

In the fourth contribution, Denise Merkle studies the publishing company Vizetelly \& Company as (ex)change agent and looks at the mod- 